\title{
U.S. Latinos’ Use of Written Spanish: Realities and Aspirations
}

\author{
Laura Callahan \\ The City College of New York
}

\begin{abstract}
This paper reports on an investigation of writing in Spanish in the lives of U.S. Latinos. Twentytwo semi-structured interviews were conducted with informants recruited from among students and former students of high school and college Spanish courses. The interviews were transcribed and coded for concepts and emergent themes (Rubin \& Rubin, 2005; Bogdan \& Biklen, 1992). Some themes that emerged relate to what U.S. Latinos do with written Spanish and what they would like to be able to do; other themes include classroom experiences, extra-academic avenues of acquisition, the social position of varieties of Spanish, language maintenance, and intergenerational loss. Themes were grouped into four categories: Spanish language maintenance and loss, issues of prescriptivism, the experience of writing in Spanish, and current and planned uses for written Spanish. The results reflect some common patterns in objectives for and obstacles to using written Spanish. The experiences and insights will be of interest to those who are involved in the disciplines of heritage language education and language maintenance in Spanish, in particular at the college level, as well as to individuals concerned with hiring biliterate professionals.
\end{abstract}

\section{Introduction}

Valdés (2000) asks:

Are our current goals for heritage speakers of Spanish coherent with the personal and professional goals of these young people? All too often our goals for heritage language students are dictated by departmental traditions and curricula. Responding to pressure from colleagues, we often focus almost exclusively on preparing students for the next-level classes. (p. 42)

Benjamin (1997, p. 2) states: "By stressing the written form [...] we may find ourselves in an uncomfortable position. Our students' reasons for studying Spanish may not jibe with our professed goals." She points out that "using the written form commonly requires that students use the prestige variety of Spanish” (1997, p. 3). She asks what students want from their Spanish classes. The present investigation asks a different, albeit related, question. Following the assumption that curricular emphasis in Spanish for Native Speakers (SNS) and Spanish for Heritage Speakers (SHS) will continue to be based on writing and acquiring a prestige variety, ${ }^{1}$ I set out to discover what members of a group of U.S. Latinos use written Spanish for, what they want to use it for, and what their experiences in using it have been.

The argument has been raised that the extra-academic spheres in which U.S. Latinos will use their Spanish may not require a command of the formal written language (Villa, 1996). This may indeed be the case for some individuals, but it nevertheless points to the need to ask students themselves what they wish to do with written Spanish. While some students report objectives for 
which a command of formal registers is unnecessary (Bernal-Enríquez \& Hernández Chávez, 2000), others express an explicit desire to acquire such registers (Acevedo, 2003).

The designations SNS and SHS will be used interchangeably in this paper, to refer to Spanish courses intended for students who arrive in the classroom having had prior contact with Spanish in the home. ${ }^{2}$ Work focusing on native and heritage speaker writing in Spanish has examined pedagogical approaches, student writing strategies, and students' reactions to instructors' attempts to correct non-standard oral and written language. In what follows I review papers that focus on teaching written Spanish to native and heritage speakers, chiefly at the college level. ${ }^{3}$ This brief literature review is not meant to set the direction for my paper, the overarching purpose of which is stated in the first and final paragraph of this introduction. However, the articles outlined contain useful background information for some issues raised by my informants, particularly with respect to issues of prescriptivism and the experience of writing in Spanish (see sections 3.2 and 3.3).

\section{Teaching Writing in the Heritage Language}

Chevalier (2004) proposes a pan-linguistic pedagogical model for teaching writing skills in the heritage language. It includes six writing modes, ranging from conversation-“composing written forms of conversational discourse"-to description, narrative, evaluation, explanation, and argument. Each writing mode has sample discourse types and target topics. For the most basic stage, conversation, the discourse types are dialogues and interior monologues, with orthography and punctuation as target topics. The target topics are not necessarily unique to each step. For example, the need to develop intersentential cohesion begins at the second stage and is present in each successive phase.

Colombi (1997, 2000) details the differences between oral and written language, especially written academic registers. Focusing, on logical connectors, among other aspects, she advocates explicit instruction in functional grammar to help students move from the interpersonal style characteristic of everyday speech to the abstraction and context reduction of academic registers. Colombi sees academic registers as imperative for the very maintenance of Spanish in the U.S.:

El mantenimiento del español como lengua minoritaria depende del desarrollo de los registros y usos que van más allá del hogar y la comunidad, en otras palabras, si realmente queremos mantener el español como una lengua viva dentro de los Estados Unidos es importante desarrollar aspectos del discurso académico que le permitirán a sus hablantes desenvolverse en un ambiente público. (Colombi 2000, p. 296)

'The maintenance of Spanish as a minority language depends on the development of registers and uses that go beyond the home and community, in other words, if we really want to maintain Spanish as a living language within the United States it is important to develop aspects of academic discourse that will permit its speakers to participate in a public sphere.' (my translation) ${ }^{4}$ 
Research on students' writing processes in the heritage language

Schwartz (2003) used questionnaires, think-aloud protocols, and interviews to discover how heritage speakers wrote an essay in Spanish. Her informants used strategies reported by many of the participants in the present investigation, such as writing what one hears, and writing via translation from English into Spanish. The writer's translation from the dominant written language leads to the "backwards biliteracy" spoken of by García (2002) and by Martínez (2007), in which English mechanical and rhetorical features appear in heritage speakers' written Spanish. Martínez finds more evidence of English influence in student narratives written for a grade than in those produced during a free writing session. Spicer-Escalante (2005) also notes differences in rhetorical strategies that affect heritage speakers' writing. ${ }^{5}$ These processes have been called interference or transfer, and for Hornberger (1989/2003), they are not necessarily negative:

[...] (a) what appears to be interference from L1 in L2 is better construed as evidence for learning in that it represents the application of L1 knowledge to L2, and (b) the stronger the foundation and continuing development in L1, the greater the potential for enhanced learning of L2. (Hornberger, 1989/2003, p. 19; emphasis in the original)

First versus second language is a famously imprecise concept in the context of heritage languages. The educational experiences of most of the informants in this study have privileged English in written contexts. Hence, that language could be considered as having a role equivalent to the L1 and Spanish the L2.

\section{Curricular Issues}

Benjamin (1997) affirms the need to include students' perspectives in the design of SNS courses. Her study's six subjects included five fifth-graders and one high school student. The fifth grade class Benjamin observed was focusing on the history of Spain at the time of her data collection, and the high school student's course focused on themes and literary style. Benjamin (1997) contrasts her informants' goals with those of their teachers:

Their goals were immediate: to use their native tongue to explore who they were. Their teachers' goals seemed more long-term: to prepare the children with basic literacy skills and knowledge for future studies in Spanish. To that end they were trying to provide their students with a broader pan-Hispanic identity. (p. 5)

Benjamin reports anecdotal evidence from university students that corroborate the foregoing complaints of these younger students about the writing instruction they were receiving.

Potowski (2002) used focus group interviews and questionnaires to investigate SHS students' and graduate student instructors' attitudes to the presence of SHS students in Spanish as a foreign language (hereafter SFL) courses. Potowski advocates increasing the training given to teaching assistants on SNS issues, and reminds us of the phenomena repeatedly seen when SFL 
and heritage learners are classmates: the former are intimidated by the latter's advantage in oral production, and the latter are demoralized by the former's greater analytical knowledge of the language.

Echoing Valdés (2000) and Benjamin (1997) quoted above, Schwarzer and Petrón (2005, p. 569) conclude: "Based on our teaching experience, we believe that a careful balance needs to be struck between what students want to know and what educators want them to know." They explore three students' perceptions of a heritage language class and solicit the students' design for the perfect Spanish course. The authors critique a SHS course that was identical to a course aimed at SFL learners, which offered primarily decontextualized grammar instruction. It is important to note that, while this is unfortunately not uncommon, many conscientiously designed SNS courses exist that do address heritage learners' different instructional requirements.

There has been little research on U.S. Latinos' aspirations and their ultimate uses for writing in Spanish. The present investigation aims to take a step in this direction, by asking students and former students for what specific purposes they have used, currently use, and would like to use their written Spanish. The decision to include informants who are no longer students was made in an effort to get a more accurate picture of what people use written Spanish for. While students enrolled in Spanish classes use written Spanish for school-based writing, Spanish speakers also use written Spanish for a variety of less predictable uses. ${ }^{6}$

\section{Method}

Semi-structured, responsive interviews were conducted with twenty-two students and former students between October 2005 and April 2006. According to Rubin and Rubin (2005, p. 37), "[r]esponsive interviewers elicit from the conversational partners examples, narratives, histories, stories, and explanations." Hence, the researcher guided the interview to maintain the focus on writing in Spanish, but informants were encouraged to discuss other experiences as they deemed appropriate. The language of the interview was determined by each informant; three interviews were conducted entirely in Spanish, and the rest were conducted primarily in English with occasional exchanges in Spanish. The basic questions included in each interview, not necessarily in this order, were:

- How did you come to know Spanish?

- What have you used written Spanish for in the past?

- What do you currently use written Spanish for?

- What would you like to be able to use it for?

- Do you have all the skills you need to use it for that purpose now?

- If not, how do you plan to get those skills?

- How do you react to criticism of your written Spanish?

- How would you compare the experience of writing in Spanish to writing in English?

- What's the most difficult aspect of writing in Spanish?

- What's the most rewarding aspect of writing in Spanish? 
These questions were intended to "prime" the conversation on the use of written Spanish. The informants' responses suggested several major themes; it is those themes, rather than these exact questions, on which the results of the investigation will be centered. In the qualitative tradition, these questions are "open-ended and concerned with process and meaning rather than cause and effect” (Bogdan \& Biklen, 1992), and are substantive rather than theoretical. Nevertheless, the experiences and understandings of these twenty-two U.S. Latinos may have broader relevance. Their experiences and insights will be of interest to those involved in heritage language education and language maintenance in Spanish, especially at the college level, as well as to those concerned with hiring biliterate professionals.

Seven of the informants were recruited by a flier distributed to students in advanced Spanish courses at a four year commuter college; the remaining fifteen were living in the same metropolitan area and responded to a posting on the online bulletin board craigslist. The announcement solicited the participation of volunteers aged eighteen or older who were members of a Latino ethnic group, had received all or part of their high school education in the United States, and who could speak and write at least some Spanish. ${ }^{7}$ Compensation for participation was forty dollars. Interviews lasted from 30 to 45 minutes.

The usual demographic information was obtained in the course of the interview, such as age, country of origin, age of arrival in the U.S., and language dominance (see Appendix A). These data were gathered for informational purposes only and were not used to seek correlations with other variables. However, the data reflect the diversity of a typical class in which Spanish is the vehicle of instruction at a public university in the U.S., with respect to age, country of origin, generation of immigration, socioeconomic class, variety of Spanish spoken, Spanish proficiency level, and knowledge of English and other languages. ${ }^{8}$ In such a class, some students have had secondary and post-secondary education with Spanish as the vehicle of instruction in a Spanishspeaking country. Many, however, lack this experience, some because they have had limited educational opportunities prior to immigration, and others because they immigrated to the U.S. at a younger age, where they continued their studies in English or in bilingual programs with an emphasis on rapid transition to English. Still others were born in the U.S. Hence, there is variation in written Spanish proficiency across this population.

Of participants recruited to participate in the present study, nine were men and thirteen were women, ranging from 18 to 62. Ten were students at the time of the interview: seven at the four year commuter college mentioned above, and three from institutions in the same public university system. Of the remaining twelve, all had finished high school and most had attended college. All but one had taken Spanish classes in high school, college, or both. The classes they mentioned ranged from SFL to SNS to advanced level literature courses.

Chevalier (2004, p. 1) makes a distinction between "heritage learners whose proficiency ranges from English-dominant students with no writing ability in their heritage language to those with some limited writing skills" and "heritage learners with native proficiency (spoken and written), who seek instruction to maintain their high-level skills.” While students with no writing ability in Spanish can be excluded from the present discussion, attempts to separate those with some 
writing skills from those who have high level skills are, for the purposes of this study, impractical, and do not reflect actual classroom situations. In U.S. post-secondary institutions, students with a wide range of proficiency levels must be accommodated all within the same course. As Edstrom (2006) notes, non-native and heritage speakers of Spanish may share the classroom with native speakers who have received some university instruction or even a degree from an institution in their country of origin. In my own experience, native speakers' higher education in a Spanish-speaking country is not always a predictor of high level skills in written academic Spanish.

The interviews were transcribed and coded for concepts and emergent themes (Rubin \& Rubin, 2005; Bogdan \& Biklen, 1992). Some of the themes that emerged explicitly address the question of what U.S. Latinos actually do with written Spanish and what they would like to be able to do, and others relate to matters such as classroom experiences, extra-academic avenues of acquisition, the social position of different varieties of Spanish, language maintenance, and intergenerational loss. The themes were grouped into four major categories, which will be examined in the following sections: 1) Spanish language maintenance and loss, 2) issues of prescriptivism, 3) the experience of writing in Spanish, and 4) current and planned uses for written Spanish.

\section{Results}

\subsection{Spanish Language Maintenance and Loss}

It is to be expected that conversations concerning a heritage language will elicit references to the maintenance or loss of that language. In the interviews done for this study, these references emerged when interviewees discussed the following topics: life stages and language use, interaction with parents and other family members, religion, intergenerational transmission of Spanish, vocabulary maintenance and loss, and the rewards of writing in Spanish.

Early fluency followed by language loss, sometimes followed in turn by resumed contact, is a common pattern for immigrant languages in the United States (e.g., Lynch, 2000; Hinton, 2001). Examples of this pattern from the interviews include loss occasioned by relocation to an Englishspeaking environment, as in the case of an informant who had spent parts of her childhood in Spanish and English-speaking countries. A classic cause of heritage language loss is the commencement of formal schooling. Heritage language loss in a school setting may be compounded if teachers and peers discourage its use. An informant describes how at school, Spanish was considered unnecessary or even undesirable:

I was kind of embarrassed to speak in the language. I knew that I knew how, but since I was in an English-speaking school, [...] at that time it wasn't such an accepted thing to be bilingual. (003)

Parents were described as a major influence in language maintenance, although their influence did not always extend to writing. Reflected in the informants' narratives was the familiar pattern of childhood resentment turning to gratitude as the informant reached adulthood. As one young woman put it, "it's like one of those skills that I never appreciated ... when I was younger I felt 
like my parents were forcing me" (019). In other cases, informants expressed regret that they had not attended more to their parents' wishes, or that their parents had not insisted on more use of spoken and written Spanish.

Several informants mentioned religion as an important influence on their Spanish competence. Reading the Bible, attending catechism classes, and using prayer cards (cf. Ek, 2005) gave them opportunities early in life mostly to read in Spanish but also to write. The sole informant who had never taken Spanish in school had become partially literate in the language from reading the Bible.

Several participants expressed a desire to be able to teach their children to speak and write in Spanish. Some mentioned their own or others' parents, who had failed to ensure written Spanish language development in their offspring, vowing not to repeat this mistake. Some participants described how they would introduce their children to written Spanish, and how they planned to or were providing their child with an environment rich in Spanish language.

Members of the second generation recognized their parents' role in their ability to use Spanish, and some tried to do the same for their own third generation children. But the second generation's circumstances were different; they were not monolingual or dominant in Spanish and therefore were unable to provide their children with a similar environment. In the pattern common to all immigrant languages in the U.S., the second generation's decreased use of Spanish in the home is resulting in the loss of productive abilities by the third generation. Even as informants noted that the generation after theirs was not learning the language, they seemed to have no firm idea of how to arrest this loss:

[...] I'm a second generation Dominican American, and so Spanish was what we spoke at home. And when I was younger obviously I took it for granted, the fact that using Spanish or a second language was a skill or an asset. And now with my own children, and nephews and nieces, they're second and, third generation or whatever, I see how hard it is for them to learn, because we as parents now, primarily speak English. And we communicate with our wives and daughters, mothers and everyone in English, and so it's blatantly obvious they're not getting that informal training that we did. And they don't have those Spanish skills. Like, like my nieces and my daughters, they can formulate a sentence if we force them to, but they probably wouldn't have a clue how to write one. So I think that now, I mean especially with my children and passing that on, I think that I'm more cognizant of how I want to implement that into my life in the present and the future. I'm not sure how, but I think I’m just more cognizant of it. At least from a speaking standpoint. (014)

It was common for the informants, the majority of whom were English dominant, to report consulting with parents and older family members when writing in Spanish for both academic and non-academic tasks. As long as they had access to family members who could help them, some seemed unconcerned about lacunae in their own knowledge of the language. Others, 
however, wished to be able to perform certain writing tasks independently and expressed frustration at having to ask for help.

Some participants, although they were aware of the language loss in progress, had not yet taken active steps to counteract it. Lack of regular use was cited as the cause of loss. Unlike in the case of English, which had been the vehicle of school instruction for most of the informants, acquisition and maintenance of written Spanish required them to exert a conscious and concerted effort. They had to invest time and money in college courses or study abroad. They had to actively pursue opportunities to use written Spanish. Those who had chosen to specialize in disciplines other than Spanish were unable to fit Spanish courses into their schedule:

I was still busy in psychology, which is what I majored in. [...] so I just had a whole bunch of psychology courses and writing twenty-page papers in English in psychology. Spanish was really at the back burner. (004)

I wanted to, in college, but [...] the way that my business major was structured, [...] I only had three classes I could take as electives. [...] it just worked out that I ended up taking another marketing course so I could try to graduate on time. (019)

When asked to name the most rewarding aspect of using written Spanish, interviewees valued the ability to write as an end in itself, or as a way to maintain or re-establish a connection to one's culture and personal heritage:

I think that although it's good to, for, you know, your resume, and jobs; I think that's just a part of not losing who you are. That's basically it: I'm Dominican, and I speak Spanish. If I speak Spanish, why can't I know how to write it properly? (011)

It just makes me proud to know that I know the language of my parents, like, speak, like the fact that I'm able to actually make cohesive sentences with paragraphs, [...] actually write a report in Spanish. That alone is just rewarding to me. (019)

Poder expresarme en el idioma de mis padres, el idioma que yo heredé, poder expresarme. So para mí es como una conexión más con mi cultura. (012)

'To be able to express myself in the language of my parents, the language I inherited, be able to express myself. So for me it's like another connection to my culture.' (my translation).

\subsection{Issues of Prescriptivism}

In the interviews, issues of prescriptivism emerged in two main areas: 1) comparison of one's own Spanish with other varieties; and 2) encounters with authority figures who defined what the correct form of the language was. For these interviewees, the incorrect form of Spanish was most 
often synonymous with, first and foremost, Spanish in contact with English, and second, with other stigmatized varieties such as, for example, Dominican Spanish (cf. Toribio, 2000).

Interviewees used the term 'Spanglish' as a term for Spanish that showed contact with English. When informants mentioned Spanglish, they were referring to the superficial manifestations of two languages' coexistence, rather than any deeper, structural modifications (cf. Otheguy, 2003). When asked to give examples of what Spanglish is, informants cited two phenomena: nouns or verbs that had been borrowed from English and adapted to Spanish phonology and morphology, or code switching between the two languages.

Informants believed that using what they referred to as Spanglish was inappropriate for formal contexts. For example, an informant who described code switching in text messages and email to his friends followed a different procedure when composing emails to a client. To avoid using both languages in the same communication, he wrote entirely in one language or the other. In cases where he was unable to find Spanish language equivalents to English language business vocabulary, he opted to write entirely in English.

Another participant described writing an essay for the bilingual education assessment section of a national teaching certification exam:

I had to write like a half a page or, you know, about this long, you know, about that program in complete Spanish, you know, no Spanglish at all. (003)

However, some informants used code switches and borrowings in their creative writing. Those who practice creative writing, even when they intend it for an audience other than themselves, often enjoy more freedom from convention than texts written for other purposes (Callahan, 2004a, 2004b; Montes-Alcalá, 2001). Still, some of these writers aspired to produce a text written entirely in Spanish, as will be seen in Section 3.4.

Informants who had used written Spanish prior to doing so in school reported having received little or no feedback on their non-academic uses of the language. Outside school they had written in Spanish mostly for personal correspondence, and their readers tended to be fairly uncritical. However, criticism and correction of writing in Spanish was offered in school.

Having their writing corrected was a defining part of the interviewees' experience, whether positive or negative, with formal instruction in the language. Some interpreted the existence of alternative vocabularies to mean that their variety, whether influenced by contact with English or regionalisms from community members' country of origin, was not legitimate. As one person, referring to the non-contact equivalents for joldup and super, i.e. holdup and building superintendent, remarked, "It was very, like, shocking to me, that there were real words for these things" (003). ${ }^{9}$ The belief that only those words found in dictionaries and textbooks are legitimate and any language variations, including those not caused by contact with English, is considered colloquial, is a common prescriptive notion. See Appendix B for examples from the interviews. 
Informants identified the Spanish taught in school as proper Spanish. One person hoped to continue studying Spanish with the goal of being able to teach her children a different variety than the one she had acquired from her parents:

And like, hopefully teach my own children proper Spanish. Because then I'll just be teaching them what I've learned from my parents, and you, it might not be all that proper either. They might need it more in future than, you know, it's helped me a lot, so it could help them even more. So, I would teach them, you know, the exact, proper Spanish also. (004)

Several informants expressed a fascination with the lexical variety they were exposed to in high school or college classes. For some, this experience instilled an appreciation of other Latino ethnic groups, and for others, it was another occasion for an authority figure to correct a nonstandard usage or for them to compare their own variety with what they considered to be a superior one. In their characterizations of standard Spanish, informants frequently used the term Castilian Spanish, usually as a cover term for any normative variety, as opposed to the dialect spoken in Central and Northern Spain.

\subsection{The Experience of Writing in Spanish}

Informants framed their experiences writing in Spanish in terms of strategies, difficulties, and satisfactions. One difficulty involved the division between spoken and written language. Tannen (1982) considers speaking and writing to be on a continuum rather than strictly separated. ${ }^{10}$ Based on the interviewees' reflections, distinguishing between them can be a particular challenge for heritage speakers. Features of spoken discourse are common in the writing of individuals whose primary experience with a language has been oral (Colombi, 1997). Speakers who assumed that oral proficiency guarantees an aptitude for written production discovered that this assumption is not true: "I didn't think that there would be so much difference between writing it and speaking it, but there are people that cannot write at all” (003).

Informants recognized the need to write differently from the way that they spoke, such as to use more sophisticated words or different forms of address, or to avoid colloquial language:

And I don't feel that I have that much vocabulary to write well in Spanish. Basic Spanish can get me by in conversation [...] (001)

[...] that's complicated to me sometimes, because there's just some things that you'll say, but then you can't really write them the same way. [...] I think it's a little more difficult for me to write in Spanish. Depending on, because most of my experience in Spanish is verbally speaking, is with people that I know, you know, and I know that when I write, it's usually to reach a larger audience or someone that I don't know. (003) 
[...] it's so different, you know, it's like when you're writing it and speaking it, sometimes you tend to say different things in terms of meanings, but with Spanish, you know, [...] it's good to know both. Speaking and writing, you know. (007)

Many interviewees described writing behavior often practiced by SFL learners: thinking first in English and then translating, sometimes word for word, into Spanish. One person said that she incorporated translation into a SNS course instead of expecting students to write directly in Spanish. Another advocated using both English and Spanish versions of Spanish language literature because, in her experience in a college literature course, "if I would have known what the poem meant in English, [...] I would have been so much more appreciative of it being taught to me in the language that it was written in" (003). Nevertheless, more of the informants expressed a desire to be able to think directly in Spanish without having to filter an utterance through English. They considered the need to take this intermediate step to be a hindrance to fluent communication, whether spoken or written, and said that having to translate from English was for them one of the more difficult aspects of writing in Spanish. Nonetheless, writing in Spanish by means of translation was the most frequent strategy cited.

The informants' next most popular strategy was to write what they heard, which was used on both a local and global level. In regard to spelling, informants had been taught to take advantage of the close correspondence between the phonetics and orthography of Spanish. Informants also described uttering a phrase or sentence aloud and drawing on their intuitive knowledge to test if it were acceptable in terms of morphosyntax and vocabulary. One person said she made use of her own competence in Spanish as well as recalling words or phrases she had heard others utter.

Writing by ear helped informants get something down on paper. Next came the task of making what they had written resemble standard forms. The majority of informants mentioned accent placement as the most difficult aspect of writing in Spanish. One claimed that in Colombia, her country of origin, it was acceptable to omit the written accent, and that she herself simply didn't "do the accents. Never tried it, never will” (005). ${ }^{11}$ Interestingly, a native of Mexico City in a Spanish M.A. program in California several years ago reported the same. She had tried unsuccessfully to convince a professor, a Spaniard, that accent placement was given no emphasis in school in Mexico, and that therefore she should not be required to use accents in her writing for the course. In the absence of a more thorough investigation, it bears noting that other informants do not corroborate these two individuals' affirmations. Beyond the scope of this article, however, the issue of pedagogical practices and expectations in Spanish-speaking countries bears further investigation. As Villa (1996) notes, out-group varieties such as those spoken and written by the upper class in Latin American countries frequently supply the benchmark for defining the form that Spanish in U.S. universities must take.

When informants used the word grammar, they were usually talking about mechanical aspects such as spelling, accents, punctuation and, to a lesser extent, verb conjugations and constituent order. Students whose primary exposure to Spanish had been oral were surprised to learn that 
Spanish, like English, had a morphosyntactic structure with corresponding terminology. As one person stated:

Yes, it very, it was very, like, shocking to me [...] that there was actually a way to understand like the tenses and, you know, the grammatical structure of Spanish besides what I thought was, you know, the way you learned English with the pronouns and the past tense and these forms, the conjugations and things. I never saw it in that way. I just learned it through verbal, you know, communication. I didn't learn it, like, in school, you know. So, it was very shocking to me to know that there was the same format to learn. (003)

As part of most formal instruction, students must learn the metalanguage of grammatical terms, and, as noted above, native and heritage speakers are often at a disadvantage in this area. Unlike non-native speakers, they have already had years of exposure to the language, and it can be difficult to integrate their old, intuitive knowledge with new, analytical knowledge. When the latter is prized over the former, the abilities that heritage speakers do have lose some value, at least in the language classroom:

[...] it was easier for me because I came from a Spanish-speaking home, as opposed to the students who didn't have Spanish-speaking at home, it was a lot harder for them. But even being easier for me, it wasn't that easy, it wasn't that easy. Because I had to learn the grammar which I didn't know. I just spoke it, the way I learned to speak it at home, Ok. So when it came to the grammar, and explaining why this was this way and why this was this way, that was hard, because I just wanted to speak it. Ok? I didn't want to deal with all the technicalities, as to why, you know, the grammar was like that. (022)

When asked to compare the experience of writing in Spanish and in English, several informants stated that writing in Spanish was more difficult, due to the factors discussed above. In spite of the difficulties, however, they expressed satisfaction that they could write in Spanish.

\subsection{Current and Planned Uses for Written Spanish}

Table 1. Summary of Participants' Current and Planned Uses for Written Spanish

\begin{tabular}{|l|}
\hline Personal correspondence \\
\hline Translation \\
\hline Academic essays \\
\hline Professional journalism and copywriting \\
\hline Creative writing \\
\hline
\end{tabular}

The pattern of current and planned uses informants reported for their written Spanish was similar across the corpus. For most, writing in Spanish began with personal correspondence, in notes and letters written to older family members in the U.S. and to relatives of all ages living in a Spanishspeaking country. If the informant was currently enrolled in or had taken a Spanish class, they 
had experience writing short compositions in Spanish. Although some informants mentioned taking classes to refine their written Spanish to accomplish other objectives, only one person named academic writing itself as a possible goal. Others wanted to improve their writing, for example, to compete for a position with a Hispanic advertising firm or as a free-lance writer for Spanish language magazines, or to pursue creative writing.

By far the most mentioned use for written Spanish was translation. Interviewees reported performing translation for friends and family members, and some had also done the occasional translation at work. More often than not, however, this translation turned out to be sight translation of forms and official correspondence from English into Spanish. In other words, the informant would read a form or letter written in English, and then give a verbal translation into Spanish. Nevertheless, a few people had actually completed written translations of forms and letters, usually on an informal basis their official job responsibilities did not include translation, and they received no extra compensation for their linguistic abilities. Informants often translated for altruistic motives, especially when informants were outside the workplace. Examples include helping strangers in hospitals and social service offices, usually with sight translation. One person who hoped to become either a social worker or bilingual special education teacher aspired to use her written Spanish for correspondence with parents, in part to prevent negative consequences; she cited high profile cases involving failures of the local child protective services system.

Two informants had used written Spanish to help their parents with gateway encounters. Each had had help from someone else. In one case, a young man translated from English into Spanish an employment exam for his mother, and his father and uncle helped. A second young man and his girlfriend translated questions into Spanish to help his mother prepare for a permanent residency exam. This experience was one of very few opportunities to write in Spanish:

I can still write in Spanish, if I chose to. I just, I haven’t lived with my mother for a couple of years, so, as far as writing in Spanish, I only do things like if I show up at her house. And she was trying to get, she actually got her green card not too long ago, so I was helping her out with all that stuff. Like all the questions, like colors of the flag, and I had to translate like all these hundreds of questions into Spanish. (016)

Informants' planned or actual use of Spanish for creative writing included poetry, short stories, song lyrics, drama, novels, and screenplays. In a couple of cases, informants considered their abilities to be on par with such a task, but most aspired either to polish their skills or acquire more skills in written Spanish to attain their creative objectives. The work that they had done or aspired to do included writing poetry that incorporated Spanish words into English language verse, translating short stories from English into Spanish, and writing entire pieces directly in Spanish. Informants' comments in Appendix C show that this last proposition was intimidating to some, and also that the ability to write something entirely in Spanish would be of great value to their sense of identity. 


\section{Discussion}

In the interviews, twenty-two native and heritage speakers of Spanish examined the place written Spanish has in their lives. The issue of Spanish language maintenance and loss was present to some degree for every person in the group and affected either them or their children or grandchildren. Some spoke of plans to stop this language loss, but most of these plans had not been put into motion.

All informants had encountered and in many cases espoused some form of prescriptivism. Prescriptive attitudes surfaced in the expected venues, in school or in the company of Spanish speakers of prestige dialects. In particular due to contact with English, but also due to the presence of other stigmatized lexical and phonetic variation, some informants differentiated their own variety of Spanish from what they called true Spanish.

The experience of writing in Spanish offered some of the same mechanical challenges for these U.S. Latinos as it does for writers in Spanish-speaking countries, as well as cognitive stumbling blocks on the bridge from spoken to written language. Use of written language usually equates to using whatever dialect is accepted as standard, as mentioned above (Benjamin, 1997). Choosing a standard presents an additional challenge, especially when the differences between a nonstandard variety and the one prescribed for producing written language are subtle. The less salient the differences are, the harder it may be for the writer to perceive them, slowing acquisition of standard forms (Valdés, 1997).

Because of the difficulty involved, the ability to write in Spanish probably offered more or a different type of satisfaction to these U.S. Latinos than to their counterparts in Spanish-speaking countries. Not all speakers can use the written form of a language, even in countries where it is dominant, and fewer can do so in a nation where another tongue is the vehicle of instruction and of most official communication. Hence the ability to write in Spanish has value for its relative scarceness.

A sample of twenty-two people cannot be extended in a statistical sense to a larger population. However, there is no reason to believe that members of this group are unique, either. Following Rubin and Rubin (2005, p. 67), I stopped recruiting interviewees once I began hearing a repetition of essentially the same types of cases.

The present investigation has shown that the ability to use written Spanish seems to play an important part in some informants' identity, by making a connection between ethnicity and language. For most, however, this connection is made by spoken Spanish, and the written form has a minor role. To be sure, writing is used for occasional correspondence and for translation, although a large portion of translation involved not writing but reading in English and then providing an oral equivalent in Spanish. A little over a quarter of the informants used or hoped to use Spanish for creative writing. It is possible that this percentage is higher than would be found in a larger sample, due to self-selection: although the forty dollars' compensation was a key factor in attracting interviewees, individuals who used written language for non-everyday purposes may have been more apt to want to share their experiences. Writing in Spanish was not 
central to the primary occupation of any of the creative writers, a subset that included students majoring in business and in English, an accountant, and a funeral home director.

Deficiencies identified on SNS and SHS placement tests include orthographic errors ${ }^{12}$ as well as vocabulary and sentence structure that do not reflect conventional choices for academic Spanish. Table 2 illustrates some of the features commonly seen in student work.

Table 2. Types and Examples of Non-standard Usages in Written Spanish

\begin{tabular}{|c|c|c|}
\hline & Non-standard form & Standard form \\
\hline \multirow[t]{2}{*}{ Misspellings } & $\begin{array}{l}\text { cojiendo clases } \\
\text { 'taking classes' }\end{array}$ & $\begin{array}{l}\text { cogiendo clases } \\
\text { 'taking classes' }\end{array}$ \\
\hline & consentrarse 'to concentrate' & concentrarse 'to concentrate' \\
\hline Missing accent mark & dificil 'difficult' & difícil 'difficult' \\
\hline $\begin{array}{l}\text { Calque from English (with } \\
\text { misspellings) }\end{array}$ & $\begin{array}{l}\text { dies pajinas largas 'ten pages } \\
\text { long' }\end{array}$ & $\begin{array}{l}\begin{array}{l}\text { de diez páginas 'ten pages } \\
\text { long' }\end{array} \\
\end{array}$ \\
\hline $\begin{array}{l}\text { Second person familiar vs. } \\
\text { impersonal }\end{array}$ & $\begin{array}{l}\text { tienes un ensayo de tu clase de } \\
\text { inglés 'you have an essay in } \\
\text { your English class' }\end{array}$ & $\begin{array}{l}\text { hay un ensayo en la clase de } \\
\text { inglés 'there's an essay for } \\
\text { English class' }\end{array}$ \\
\hline
\end{tabular}

Many individuals interviewed identified these features in their writing. Some were unconcerned with them and others wished they could use more standard forms.

\section{Conclusion}

This investigation has offered a glimpse into the use of written Spanish in the lives of a group of U.S. Latinos. Overall, the group's use of written Spanish is fairly minimal. Though some interviewees spoke of plans to write entire books in Spanish, at the time of the interviews their actual use was limited to private diaries. It could be argued that gaps in vocabulary and other difficulties that were mentioned cause the informants to write in Spanish less. Then we would have to consider how much one influences the other: do individuals with fewer skills engage in an activity less often, or does their less frequent engagement lead to their lack of skill? It would be logical to assume a relationship of mutual influence. However, informants in this group who had the most proficiency in written Spanish were among those who used it the least on a day to day basis. Other informants lamented their limited opportunities to write in Spanish, and I would argue that this area is an urgent avenue for investigation: how can U.S. Latinos who wish to develop their written Spanish do so, given the other demands of their daily lives?

This question goes beyond the scope of the high school and college campus, which is one reason that participants for this study were not all recruited directly from the classroom. ${ }^{13}$ Few venues are available to most people to use formal written Spanish once they leave school. Modifications in teaching methodologies, however worthwhile, offer only partial remedies to this problem. Nevertheless this study suggests some pedagogical implications, curricular in nature. What we who are in language departments can do is strive to reserve a space for written Spanish ${ }^{14}$ within the academic environment, so that more students might fully maintain or develop their linguistic skills as well as become potential candidates for extra-academic opportunities in the labor 
market. ${ }^{15}$ Some language and literature departments offer writing courses in English, in which literature is read in translation. These courses are often taught in departments offering languages with small enrollments and in those without a practice of teaching upper division courses ${ }^{16}$ in the target language, but neither factor is a consideration in most departments of Spanish in the United States.

Administrative pressures, however, can play a role in minimizing the number of classes involving writing in Spanish. A recent case at my own institution is an example. Two established fourth year content courses normally taught in Spanish were proposed as courses that would fulfill a new advanced level general education requirement. Both were accepted after much discussion of the merits of offering writing courses in a language other than English. At the last minute, a mandate was issued that all such courses had to fulfill the institution's writing intensive requirement. However, because writing intensive courses are designed to improve academic English, these Spanish content courses would have to be taught in English. Fortunately, both courses had high enough enrollments when offered in Spanish that the instructors withdrew their applications for general education status so they could continue teaching the courses in that language, thus preserving one opportunity for students to pursue academic writing in Spanish. Unfortunately, students continued to have no opportunity to fulfill two objectives at once: to practice using written Spanish and to simultaneously complete a general education requirement.

Curricular measures such as writing across the curriculum courses, in which students may pursue a research project in the language, are certainly worthwhile as well. However, the key word here is student, and remedies undertaken in a school setting, no matter how innovative, cannot address the wider dilemma of what speakers can do with written Spanish once they are no longer in school. Nor are curricular and pedagogical measures of help to U.S. Latinos who never attend college, or to those college students whose degree program leaves little room for courses beyond the major, as attested to by the interviewees quoted in Section 3.1.

The fundamental issue is the dominance of English in most written domains, with the exception of those few professions in which Spanish occupies an equal or greater amount of space. As stated above, unlike for English, which is not only the vehicle of instruction but also the language of the workplace ${ }^{17}$ for most people raised in the United States, acquisition and maintenance of written Spanish comes at a higher cost in that it requires an even more conscious and concerted effort. As we have seen, there are also costs associated with its lack of development, but these may not be high enough to convince heritage language speakers to resist the hegemony of English. The inability to resist English is especially difficult in a country such as the United States, where bilingualism has only lately come to be seen as benign and where the supportive infrastructure of societal bilingualism is minimal. ${ }^{18}$

\section{Acknowledgements}

I would like to express my deep appreciation to the twenty-two people who participated in the interviews. I am grateful for financial support from the Research Institute for the Study of Language in Urban Society, at the Graduate Center of the City University of New York, and to 
the editors of Heritage Language Journal and two anonymous reviewers for their helpful suggestions on an earlier version of this paper.

\section{References}

Acevedo, R. (2003). Navegando a través del registro formal: Curso para hispanohablantes bilingües. In A. Roca \& M. C. Colombi (Eds.), Mi lengua: Spanish as a heritage language in the United States (pp. 257-268). Washington, DC: Georgetown University Press.

Achugar, M. (2003). Academic registers in Spanish in the U.S.: A study of oral texts produced by bilingual speakers in a university graduate program. In A. Roca \& M. C. Colombi (Eds.), Mi lengua: Spanish as a heritage language in the United States (pp. 213-230). Washington, DC: Georgetown University Press.

Benjamin, R. (1997). What do our students want? Some reflections on teaching Spanish as an academic subject to bilingual students. ADFL Bulletin, 29(1), 44-47.

Bernal-Enríquez, Y., \& Hernández Chávez, E. (2003). Un enfoque funcional para la enseñanza del ensayo expositivo: ¿Revitalización o erradicación de la variedad chicana? In A. Roca \& M. C. Colombi (Eds.), Mi lengua: Spanish as a heritage language in the United States (pp. 96-119). Washington, DC: Georgetown University Press.

Bogdan, R. \& Biklen, S. K. (1992). Qualitative research for education: An introduction to theory and methods. Needham Heights, Massachusetts: Allyn and Bacon.

Callahan, L. (2004a). The role of register in Spanish-English codeswitching in prose. The Bilingual Review/ La Revista Bilingüe, 27(1), 12-25.

Callahan, L. (2004b). Spanish/English codeswitching in a written corpus. Amsterdam: John Benjamins.

Callahan, L. (2005). 'Talking both languages': 20 Perspectives on the use of Spanish and English inside and outside the workplace. Journal of Multilingual and Multicultural Development, 26(4), 275-295.

Callahan, L. (2008a). El uso del acento ortográfico en el español de los Estados Unidos, América Latina, y España: Normas periodísticas. Itinerarios: Revista de estudios lingüísticos, literarios, históricos y antropológicos, 7, 187-198.

Callahan, L. (2008b). [Review of Developing contrastive pragmatics: Interlanguage and crosscultural perspectives]. Linguist List. Vol. 19-2773.

Carreira, M. M. (2003). Profiles of SNS students in the twenty-first century: Pedagogical implications of the changing demographics and social status of U.S. Hispanics. In A. Roca \& M. C. Colombi (Eds.), Mi lengua: Spanish as a heritage language in the United States (pp. 51-77). Washington, DC: Georgetown University Press.

Chevalier, J. F. (2004). Heritage language literacy: Theory and practice. Heritage Language Journal, 2(1). Available from http://www.heritagelanguages.org

Colombi, M. C. (1997). Perfil del discurso escrito en textos de hispanohablantes: teoría y práctica. In M. C. Colombi and F. X. Alarcón (Eds.), La enseñanza del español a hispanohablantes: Praxis y teoría (pp. 175-189). Boston: Houghton Mifflin.

Colombi, M. C. (2000). En vías del desarrollo del lenguaje académico en español en hablantes nativos de español en los Estados Unidos. In A. Roca (Ed.), Research on Spanish in the 
United States: Linguistic issues and challenges (pp. 296-309). Somerville, Massachusetts: Cascadilla Press.

Colombi, M. C., \& Alarcón, F. X. (Eds.). (1997). La enseñanza del español a hispanohablantes: Praxis y teoría. Boston: Houghton Mifflin.

Colombi, M. C., \& Roca, A. (2003). Insights from research and practice in Spanish as a heritage language. In A. Roca and M. C. Colombi (Eds.), Mi lengua: Spanish as a heritage language in the United States (pp. 1-21). Washington, D.C.: Georgetown University Press.

Edstrom, A. (2006). Oral narratives in the language classroom: A bridge between non-native, heritage, and native-speaking learners. Hispania, 89(2), 336-346.

Ek, L. D. (2005). Staying on God's path: Socializing Latino/a immigrant youth to a Christian Pentecostal identity in Los Angeles. In A. C. Zentella (Ed.), Building on strength: Language and literacy in Latino families and communities (pp. 77-92). New York: Teachers College Press.

Fernández, E. (2008, March 1). The erosion of español. Miami Herald. Retrieved from http://juantornoe.blogs.com/hispanictrending/2008/03/the-spanish-spo.html Rpt.from Miami Herald.

Fox-Alston, J. (2007, August 15). Staffing issues at Spanish-language publications. Newspaper Association of America. Retrieved from http://www.naa.org/Resources/Articles/DiversityFusion-Staffing-Issues-at-Spanish-Language-Publications/Diversity-Fusion-Staffing-Issuesat-Spanish-Language-Publications.aspx

García, O. (2002). Writing backwards across languages. In M. Schleppergrell and M. C. Colombi (Eds.), Developing advanced literacy in first and second languages (pp. 245-260). Mahwah, New Jersey: Erlbaum.

González Pino, B. \& Pino, F. (2000). Serving the heritage speaker across a five-year program. ADFL Bulletin, 32(1), 27-35.

Hernández-Chávez, E. (2000, April). La lucha por el español en los Estados Unidos frente a la hegemonía del inglés. Paper presented at the $18^{\text {th }}$ National Conference on Spanish in the United States, Davis, CA.

Hinton, L. (2001). Involuntary language loss among immigrants. In J. E. Alatis \& A.-H. Tan (Eds.), Language in our time: Bilingual education and official English, Ebonics and Standard English, immigration and the Unz Initiative. Georgetown University Round Table in Language and Linguistics 1999 (pp. 203-252). Washington, D.C.: Georgetown University Press.

Hornberger, N. H. (1990). Creating successful learning contexts for biliteracy. Teachers College Record, 92(2), 212-229.

Hornberger, N. H. (2003). Continua of biliteracy. In N. H. Hornberger (Ed.), Continua of biliteracy: An ecological framework for educational policy (pp. 3-34). Clevedon, UK: Multilingual Matters. (Reprinted from Review of Educational Research, 59(3), 271-296, 1989).

Hornberger, N. H. \& Skilton-Sylvester, E. (2003). Revisiting the continua of biliteracy: International and critical perspectives. In N. H. Hornberger (Ed.), Continua of biliteracy: An ecological framework for educational policy (pp. 35-67). Clevedon, UK: Multilingual Matters. (Reprinted from Language and Education: An International Journal, 14(2), 96122, 2000). 
Leeman, J. (2005). Engaging critical pedagogy: Spanish for native speakers. Foreign Language Annals, 38(1), 35-45.

Lynch, A. (2000). Spanish-speaking Miami in sociolinguistic perspective: Bilingualism, recontact, and language maintenance among the Cuban-origin population. In A. Roca, (Ed.), Research on Spanish in the United States: Linguistic issues and challenges (pp. 271-283). Somerville, Massachusetts: Cascadilla Press.

Martínez, G. A. (2003). Classroom based dialect awareness in heritage language instruction: A critical linguistic approach. Heritage Language Journal, 1(1). Available from http://www.heritagelanguages.org

Martínez, G. A. (2007). Writing back and forth: The interplay of form and situation in heritage language composition. Language Teaching Research, 11(1), 31-41.

Mercado, C. I. (2003). Biliteracy development among Latino youth in New York City communities: An unexploited potential. In N. H. Hornberger (Ed.), Continua of biliteracy: An ecological framework for educational policy (pp. 166-186). Clevedon, UK: Multilingual Matters.

Merino, B.; Trueba, H.; \& Samaniego, F. (Eds.) (1993). Language and culture in learning: Teaching Spanish to native speakers of Spanish. Washington, D.C.: Falmer.

Montes-Alcalá, C. (2001). Written code-switching: Powerful bilingual images. In R. Jacobson (Ed.), Codeswitching worldwide II (pp. 193-219). Berlin: Mouton de Gruyter.

Neff-van Aertselaer, J.A. and Dafouz-Milne, E. (2008). Argumentation patterns in different languages: An analysis of metadiscourse markers in English and Spanish texts. In M. Pütz \& J.A. Neff-van Aertselaer (Eds.), Developing contrastive pragmatics: Interlanguage and cross-cultural perspectives (pp. 87-102). Berlin: Mouton de Gruyter.

Otheguy, R. (2003). Las piedras nerudianas se tiran al norte: Meditaciones lingüísticas sobre Nueva York. Insula, 679/680, 13-19.

Porras, J. (1997). Uso local y uso estándar: un enfoque bidialectal a la enseñanza del español para nativos. In M. C. Colombi \& F. X. Alarcón (Eds.), La enseñanza del español a hispanohablantes: Praxis y teoría (pp. 190-198). Boston: Houghton Mifflin.

Potowski, K. (2002). Experiences of Spanish heritage speakers in university foreign language courses and implications for teacher training. ADFL Bulletin, 33(3), 35-42.

Roca, A. (1997). Retrospectives, advances, and current needs in the teaching of Spanish to United States Hispanic bilingual students. ADFL Bulletin, 29(1), 37-43.

Rubin, H. J.; \& Rubin, I. S. (2005). Qualitative interviewing: The art of hearing data. $2^{\text {nd }}$ ed. Thousand Oaks, California: Sage Publications.

Schwartz, A. M. (2003). ¡No me suena! Heritage Spanish speakers’ writing strategies. In A. Roca \& M. C. Colombi (Eds.), Mi lengua: Spanish as a heritage language in the United States (pp. 235-256). Washington, DC: Georgetown University Press.

Schwarzer, D., \& Petrón, M. (2005). Heritage language instruction at the college level: Reality and possibilities. Foreign Language Annals, 38(4), 568-578.

Spicer-Escalante, M. (2005). Writing in two languages/Living in two worlds: A rhetorical analysis of Mexican-American written discourse. In M. Farr (Ed.), Latino language and literacy in ethnolinguistic Chicago (pp. 217-246). Mahwah, New Jersey: Erlbaum.

Tannen, D. (1982). The oral/literate continuum in discourse. In D. Tannen, (Ed.), Spoken and written language: Exploring orality and literacy (pp. 1-16). Norwood, New Jersey: Ablex. 
Toribio, A. J. (2000). Nosotros somos dominicanos: Language and self-definition among Dominicans. In A. Roca, (Ed.), Research on Spanish in the United States: Linguistic issues and challenges (pp. 252-270). Somerville, Massachusetts: Cascadilla Press.

Turner, J. (2004) Academic literacy in post-colonial times: Hegemonic norms and transcultural possibilities. In A. Phipps \& M. Guilherme, (Eds.), Critical pedagogy: Political approaches to language and intercultural communication (pp. 22-32). Clevedon, UK: Multilingual Matters.

Valdés, G. (1997). The teaching of Spanish to bilingual Spanish-speaking students: Outstanding issues and unanswered questions. In M. C. Colombi \& F. X. Alarcón (Eds.), La enseñanza del español a hispanohablantes: Praxis y teoría (pp. 8-44). Boston: Houghton Mifflin.

Valdés, G. (2000). Bilingualism from another perspective: The case of young interpreters from immigrant communities. In A. Roca, (Ed.), Research on Spanish in the United States: Linguistic Issues and Challenges, (pp. 42-81). Somerville, Massachusetts: Cascadilla Press.

Valdés, G.; Fishman, J.; Chávez, R.; \& Pérez, W. (2006). Developing minority language resources: The case of Spanish in California. Clevedon, UK: Multilingual Matters.

Valdés, G.; Lozano, A.; \& García-Moya, R. (Eds.). (1981). Teaching Spanish to the Hispanic bilingual: Issues, aims, and methods. New York: Teachers College Press.

Villa, D. J. (1996). Choosing a "standard” variety of Spanish for the instruction of native Spanish speakers in the U.S. Foreign Language Annals, 29(2), 191-200.

Villa, D. J. (2002). The sanitizing of U.S. Spanish in academia. Foreign Language Annals, 35(2), 222-30. 
Appendix A. Demographic Characteristics of the Interviewees

\begin{tabular}{|c|c|c|c|c|c|c|c|c|}
\hline Code & Sex & Age & $\begin{array}{l}\text { Currently } \\
\text { a student }\end{array}$ & $\begin{array}{l}\text { Self- } \\
\text { reported } \\
\text { dominant } \\
\text { language }\end{array}$ & Place of birth & $\begin{array}{l}\text { Parents' place of } \\
\text { birth }\end{array}$ & $\begin{array}{l}\text { Age } \\
\text { of } \\
\text { arrival } \\
\text { in } \\
\text { USA }\end{array}$ & $\begin{array}{l}\text { Years } \\
\text { in } \\
\text { USA }\end{array}$ \\
\hline 001 & $\mathrm{~F}$ & 35 & Yes & English & Panama & Panama & 6 & $26^{*}$ \\
\hline 002 & $\mathrm{M}$ & 21 & Yes & English & $\begin{array}{l}\text { Dominican } \\
\text { Republic }\end{array}$ & $\begin{array}{l}\text { Dominican } \\
\text { Republic }\end{array}$ & 11 & 10 \\
\hline 003 & $\mathrm{~F}$ & 32 & Yes & English & USA & Puerto Rico & 0 & 32 \\
\hline 004 & $\mathrm{~F}$ & 24 & No & English & USA & Puerto Rico & 0 & life \\
\hline 005 & $\mathrm{~F}$ & 32 & No & English & Colombia & Colombia & 7 & 25 \\
\hline 006 & $\mathrm{~F}$ & 19 & No & English & $\begin{array}{l}\text { Dominican } \\
\text { Republic }\end{array}$ & $\begin{array}{l}\text { Dominican } \\
\text { Republic }\end{array}$ & 4 & 15 \\
\hline 007 & $\mathrm{~F}$ & 31 & No & English & USA & $\begin{array}{l}\text { Dominican } \\
\text { Republic }\end{array}$ & 0 & life \\
\hline 008 & $\mathrm{M}$ & 18 & Yes & English & USA & Guatemala & 0 & life \\
\hline 009 & $\mathrm{~F}$ & 19 & Yes & English & Nicaragua & Nicaragua & 2 & life \\
\hline 010 & M & 22 & Yes & Spanish & Nicaragua & Nicaragua & 5 & 17 \\
\hline 011 & $\mathrm{~F}$ & 20 & Yes & English & USA & $\begin{array}{l}\text { Dominican } \\
\text { Republic }\end{array}$ & 0 & life \\
\hline 012 & M & 42 & Yes & English & USA & Puerto Rico & 0 & life \\
\hline 013 & M & 37 & Yes & Spanish & $\begin{array}{l}\text { Dominican } \\
\text { Republic }\end{array}$ & $\begin{array}{l}\text { Dominican } \\
\text { Republic }\end{array}$ & 30 & 7 \\
\hline 014 & M & 30 & No & English & USA & $\begin{array}{l}\text { Dominican } \\
\text { Republic }\end{array}$ & 0 & life \\
\hline 015 & M & 26 & No & English & Venezuela & $\begin{array}{l}\text { Dominican } \\
\text { Republic }\end{array}$ & 1 & life \\
\hline 016 & M & 26 & No & English & USA & $\begin{array}{l}\text { Dominican } \\
\text { Republic }\end{array}$ & 0 & life \\
\hline 017 & $\mathrm{~F}$ & 46 & No & English & USA & Puerto Rico & 0 & life** \\
\hline 018 & $\mathrm{M}$ & 19 & Yes & Spanish & Honduras & Honduras & 16 & 3 \\
\hline 019 & $\mathrm{~F}$ & 22 & No & English & USA & Colombia & 0 & life \\
\hline 020 & $\mathrm{~F}$ & 28 & No & English & USA & $\begin{array}{l}\text { Spain (mat.); } \\
\text { Cuba (pat.) }\end{array}$ & 0 & life \\
\hline 021 & $\mathrm{~F}$ & 62 & No & English & Puerto Rico & Puerto Rico & 5 & 57 \\
\hline 022 & $\mathrm{~F}$ & 51 & No & English & Puerto Rico & Puerto Rico & 2 & 49 \\
\hline
\end{tabular}

*Lived in Panama from age 1-6 and 11-14; rest of life spent in U.S.

**Spent one academic year in Puerto Rico, age 10, fifth grade. 


\section{Appendix B: Prescriptive Reactions to Variation Not Caused by Contact with English}

(B1) Like, I can say I'm going to be late. And my mom would say something like "Me voy a tardar, tanto tanto tiempo," which means I would be late for such and such a time. But the actual way you can say it is “ ¿Cuánto tiempo te vas a demorar?” Which means, it’s like, how long is the wait time? So, I would say like "tardar ['to be late']" and the professor would be, like, “No, it’s demorar ['to delay'].” (004)

(B2) Well, let's say like if I would say in Spanish "Oh, la guagua's ['bus' in Caribbean Spanish] coming", the teacher would say "That's not how you say it; you say the autobús. You know, like, so to me, saying la guagua is slang, instead of saying the autobús, which is the correct way of speaking, you know? Like that. (007)

(B3) Like my boyfriend at the time, he was actually the Dominican one that used the example, it was like sophomore year, he put down something like, say [translate] "a little bit”, and he put down un chin. And he [the teacher] was like, that's wrong. (019)

\section{Appendix C: Interviewees' Remarks on the Production of a Text Entirely in Spanish}

(C1) Interviewee: Well, I hope to continue in my creative writing with, I hope to keep using a bilingual form. I mean, I don't know if I can get to the point where I could completely write something in Spanish. Which is, you know, of course, a possibility, you know. I don't think I'll write prose or essays or short stories in Spanish, but there will always be a Spanish influence in what I write, in, at a creative level. [...] Unless I wrote a whole book in Spanish.

Researcher: Do you think that might be a possibility?

Interviewee: You kind of scared me; I would just, I have, I'm such a perfectionist, I'm very meticulous about, like, I'd just criticize myself the whole entire, because I'm not that type with the Spanish. (003)

(C2) Bueno, yo soy, I'm an English major, en literatura, so, a mí me gustaría trabajar en esta área. Y, como yo soy bilingüe, mucho de lo que yo escribo algunas veces es una combinación en inglés y español. [...] Yo pienso que todo el mundo tiene una novela, you know, en su vida, so eso ha sido, si yo me dejo, a mí me gusta soñar, me gusta tener ilusiones de lo que yo quiero hacer, y para mí un libro fuera algo ideal. [...] Yo, obviamente, yo no estoy preparado todavía para hacer, escribir un libro ni manuscript, ni nada de eso, pero, puedo seguir tomando clases para poder alcanzar esa meta. Yo no estoy, a mí, yo sí puedo hacer, puedo escribir algo, porque muchos de los escritores latinoamericanos siempre escriben en inglés, pero tienen palabras o frases en español, so, yo me siento cómodo haciendo eso. Si fuera algo completamente en español, yo no estoy en, de ningún modo preparado para eso. (012) 
'Well, I'm a, I'm an English major, in literature, so I'd like to work in this area. I, since I'm bilingual, a lot of what I write sometimes is a combination in English and Spanish. I think that everyone has a novel, you know, in their life, so that has been, if I let myself, I like to dream, I like to fantasize about what I want to do, and for me a book would be ideal. I, obviously I'm not ready yet to do, to write a book nor a manuscript, nor anything like it, but, I can keep taking classes in order to be able to reach that goal. I'm not, to me, I can do, I can write something, because many of the Latin American writers always write in English, but they have words or phrases in Spanish, so, I feel comfortable doing that. If it were something completely in Spanish, I'm not in any way ready for that.' (my translation)

(C3) Interviewee: I had recently submitted it to [major commercial publisher]. They said they had liked it, but they wanted like a thousand pages, and I've only written like maybe fifteen.

Researcher: [...] And so, your plan for that is that's going to be entirely in Spanish.

Interviewee: Yeah. It's something that I want to do for myself. (017)

\section{Appendix B: Prescriptive Reactions to Variation Not Caused by Contact with English}

(B1) Like, I can say I'm going to be late. And my mom would say something like "Me voy a tardar, tanto tanto tiempo," which means I would be late for such and such a time. But the actual way you can say it is “¿Cuánto tiempo te vas a demorar?” Which means, it's like, how long is the wait time? So, I would say like "tardar ['to be late']" and the professor would be, like, “No, it's demorar ['to delay'].” (004)

(B2) Well, let's say like if I would say in Spanish “Oh, la guagua's ['bus' in Caribbean Spanish] coming", the teacher would say "That's not how you say it; you say the autobús. You know, like, so to me, saying la guagua is slang, instead of saying the autobús, which is the correct way of speaking, you know? Like that. (007)

(B3) Like my boyfriend at the time, he was actually the Dominican one that used the example, it was like sophomore year, he put down something like, say [translate] "a little bit”, and he put down un chin. And he [the teacher] was like, that's wrong. (019)

\section{Appendix C: Interviewees' Remarks on the Production of a Text Entirely in Spanish}

(C1) Interviewee: Well, I hope to continue in my creative writing with, I hope to keep using a bilingual form. I mean, I don't know if I can get to the point where I could completely write something in Spanish. Which is, you know, of course, a possibility, you know. I don't think I'll write prose or essays or short stories in Spanish, but there will always be a 
Spanish influence in what I write, in, at a creative level. [...] Unless I wrote a whole book in Spanish.

Researcher: Do you think that might be a possibility?

Interviewee: You kind of scared me; I would just, I have, I'm such a perfectionist, I'm very meticulous about, like, I'd just criticize myself the whole entire, because I'm not that type with the Spanish. (003)

(C2) Bueno, yo soy, I'm an English major, en literatura, so, a mí me gustaría trabajar en esta área. Y, como yo soy bilingüe, mucho de lo que yo escribo algunas veces es una combinación en inglés y español. [...] Yo pienso que todo el mundo tiene una novela, you know, en su vida, so eso ha sido, si yo me dejo, a mí me gusta soñar, me gusta tener ilusiones de lo que yo quiero hacer, y para mí un libro fuera algo ideal. [...] Yo, obviamente, yo no estoy preparado todavía para hacer, escribir un libro ni manuscript, ni nada de eso, pero, puedo seguir tomando clases para poder alcanzar esa meta. Yo no estoy, a mí, yo sí puedo hacer, puedo escribir algo, porque muchos de los escritores latinoamericanos siempre escriben en inglés, pero tienen palabras o frases en español, so, yo me siento cómodo haciendo eso. Si fuera algo completamente en español, yo no estoy en, de ningún modo preparado para eso. (012)

'Well, I'm a, I'm an English major, in literature, so I'd like to work in this area. I, since I'm bilingual, a lot of what I write sometimes is a combination in English and Spanish. I think that everyone has a novel, you know, in their life, so that has been, if I let myself, I like to dream, I like to fantasize about what I want to do, and for me a book would be ideal. I, obviously I'm not ready yet to do, to write a book nor a manuscript, nor anything like it, but, I can keep taking classes in order to be able to reach that goal. I'm not, to me, I can do, I can write something, because many of the Latin American writers always write in English, but they have words or phrases in Spanish, so, I feel comfortable doing that. If it were something completely in Spanish, I'm not in any way ready for that.' (my translation)

(C3) Interviewee: I had recently submitted it to [major commercial publisher]. They said they had liked it, but they wanted like a thousand pages, and I've only written like maybe fifteen.

Researcher: [...] And so, your plan for that is that's going to be entirely in Spanish.

Interviewee: Yeah. It’s something that I want to do for myself. (017) 


\section{Notes}

${ }^{1}$ A current debate in the SNS profession-one that is beyond the scope of this paper-centers on whether it is desirable or even necessary to insist on the acquisition of a standard variety of Spanish, i.e. a variety that enjoys overt prestige. Proponents of critical linguistics call for raising students' consciousness of issues of language and power, and question the ethics of teaching students that certain varieties of Spanish are more appropriate in one setting or another (e.g., Leeman, 2005; Martínez, 2003; Villa, 1996, 2002). Others see the ability to make this discrimination as a necessary tool for students’ participation in Spanish-speaking domains beyond the home community (e.g., Colombi, 1997; Porras, 1997; Valdés, 1997). A similar debate is being held in the field of English as a Second Language. Concerns have been raised about failing to ensure that students achieve maximum control of formal written features. For example, Turner (2004) points out that a writer's deficiency in English translates to readers as a "cognitive deficiency per se" (p. 25). Turner acknowledges the imbalance of power in the evaluation of language varieties, and advocates the explicit teaching of academic literacy norms, to equip writers not only to participate in the academic domain, but also to discover ways to resist and replace existing norms. See also Hornberger and Skilton-Sylvester (2003). (back)

${ }^{2}$ For literature on the evolution of SNS programs in the U.S. and their objectives, see: Colombi and Alarcón (1997); González Pino and Pino (2000); Merino, Trueba, and Samaniego (1993); Roca (1997); Valdés, Lozano, and García-Moya (1981). (back)

${ }^{3}$ Bilingual education and ESL programs are not the focus of the present paper. In many ESL programs, and in non-bilingual programs with large numbers of children whose home language is not English, notwithstanding an increased validation of expanded definitions of literacy and of literacy in minority languages, academic writing instruction is more often than not focused on English. Cf. Mercado (2003, p. 175): “Latino students evidence surprising levels of biliteracy in the sense that Hornberger (1990) suggests. It should be clear, however, that our activities were designed primarily to motivate personally meaningful writing in a variety of academic genres in English.” (ㅁack)

4 Academic discourse is not in theory synonymous with written language, but in practice references to academic registers most often mean writing. Interestingly, when I asked students in an undergraduate Spanish linguistics course for their opinion on Colombi's assertion (in a class exercise that was not part of the present investigation), those who expressed disagreement with her cited continued immigration and large numbers of Spanish speakers, effectively sidestepping the question of whether cultivation of academic Spanish is necessary for language maintenance. (back)

${ }^{5}$ In regard to differences in Spanish and English rhetorical style, see also Callahan (2008b) and Neff-van Aertselaer and Dafouz-Milne (2008). (back)

${ }^{6}$ Valdés et al. (2006) found that among Hispanic professionals in California, the highest use of written Spanish—still very low_was among academics. (back) 
7 Due to a misunderstanding, one person who came for an interview did not fit all of these criteria. At the time of the interview he was a student at a community college, but he had received all of his high school education as well as a university degree in the Dominican Republic. Nevertheless, I decided to include his interview in the corpus because it offers observations consonant with those of other participants in regard to language maintenance and loss. (back)

${ }^{8}$ Other researchers have noted this diversity (Carreira, 2003; Colombi \& Roca 2003. p. 4). Classes in some private universities in the U.S. may be less heterogeneous, especially regarding student age. Appendix A shows a group very similar in demographic composition to classes at my current institution, which is part of a large public university system. Students' and their parents' place of birth would differ in schools located in other parts of the country, where there would be a higher representation of Mexican and Central American origins and a lower representation of Caribbean ones. (back)

9 The non-contact words for these would be 'atraco’ and 'conserje’ respectively. (back)

${ }^{10}$ For a review of studies of the oral-literate continuum see also Hornberger (2003, pp. 11-13). (back)

${ }^{11}$ See also Callahan (2008a). ( $\left.\underline{\text { back}}\right)$

12 The most common orthographic errors involve confusion of the letters $s, c$, and $z$, between $h$ and no $h$, and confusion over accent mark collocation. These features also surface in the writing of students and non-students in Spanish-speaking countries. (ㅁack)

13 Another reason for recruitment via craigslist was the greater quasi-anonymity it afforded; although participants provided their names, I did not know them as I might know students in my program's classes. This greater degree of distance was desirable to avoid the appearance or perception of coercion by an authority figure. ( $\underline{\text { back}}$ )

14 This paper's focus on the written form does not mean that oral skills should not likewise be cultivated. As Achugar (2003) has noted, heritage and native speakers of Spanish who can carry on a conversation in that language may find it difficult to give a formal presentation in an academic or business environment. (back)

15 It has been reported that U.S. Latinos often do not have the level of literacy in Spanish required for a business setting (Carreira 2003, 70-71; Fernández, 2008; Fox-Alston, 2007). Employers are thus forced to forego the bicultural expertise of such individuals and instead hire Spanish speakers raised and educated in other countries who have the required literacy skills. (back) 
${ }^{16}$ College language departments typically offer first and second year courses in basic language skills acquisition, and third and fourth year courses in literature, linguistics, and culture. Spanish is the vehicle of instruction in most of these third and fourth year courses at U.S. universities. (back)

${ }^{17}$ See Callahan (2005). (back)

${ }^{18}$ Hernández-Chávez’s (2000) statement during a plenary address that territorial bilingualism might be the only means to arrest Spanish language loss in the Southwestern United States was met with a somewhat startled reaction from the audience. (back) 